\title{
Periodisasi Perkembangan Hukum Perbankan Syariah di Kabupaten Bone
}

\author{
Juhasdi Susono \\ Institut Agama Islam Negeri (IAIN) Bone \\ Juhasdimm@gmail.com
}

\begin{abstract}
Abstrak
Pertumbuhan perbankan Islam yang cepat dan siqnificant harus didukung oleh sumber daya manusia yang berkualitas. Orang membutuhkan kepastian hukum untuk menjaga ketertiban sosial. Terkadang, orang membuat aturan untuk melegitimasi tindakan mereka atau untuk menciptakan interpretasi hukum yang baru. Karena itu, hukum yang ketat diperlukan untuk mengendalikan orang agar tidak sampai pada kesimpulan yang meminta maaf. Islam memberi manusia hukum Allah sebagai pedoman di dunia dan kehidupan di sini setelahnya. Perbankan syariah adalah sistem perbankan nasional berdasarkan hukum Islam. Perbankan Islam didirikan berdasarkan sistem ekonomi Islam. Ini bertujuan tidak hanya untuk keuntungan tetapi untuk kesejahteraan masyarakat.
\end{abstract}

Kata Kunci : Periodisasi, Ekonomi Islam, Hukum Perbankan Syariah di Kabupaten Bone

\section{PENDAHULUAN}

Bank syariah merupakan salah satu bentuk dari perbankan nasional yang mendasarkan operasionalnya pada syariat (hukum) Islam. Bank syariah dikembangkan sebagai lembaga bisnis keuangan yang melaksanakan kegiatan usahanya sejalan dengan prinsip-prinsip dasar dalam ekonomi Islam. Tujuan ekonomi Islam dalam bank syariah tidak hanya terfokus pada tujuan komersial yang tergambar pada percapaian keuntungan maksimal, tetapi perannya dalam memberikan kesejahteraan secara luas bagi masyarakat. Kontribusi untuk turut serta dalam mewujudkan kesejahteraan masyarakat tersebut merupakan peran bank syariah dalam pelaksanaan fungsi sosialnya. Fungsi sosial yang paling tampak di antaranya di wujudkan melalui aktifitas penghimpunan dan penyaluran zakat, infak, sedekah, hibah dan wakaf (ZISW). Selain itu, bank syariah juga mengeluarkan zakat dari keuntungan operasinya serta memberikan pembiayaan kebijakan (qardh). Fungsi sosial ini diharapkan akan memperlancar alokasi dan distribusi dana sosial yang dibutuhkan oleh masyarakat. (Khaerul Umam, tt: 15- 16) 
Di Indonesia, bank syariah yang pertama didirikan pada tahun 1992 adalah bank muamalat. Walaupun perkembangannya agak terlambat bila dibandingkan dengan negara-negara muslim lainnya, perbankan syariah di Indonesia akan terus berkembang bila pada tahun 1992-1998 hanya ada satu unit bank syariah di Indonesia, maka pada tahun 1999 jumlahnya bertambah menjadi tiga unit. Pada tahun 2000, bank syariah maupun bank konvensional yang membuka unit usaha syariah telah meningkat menjadi 6 unit. Sedangkan jumlah BPRS (Bank Perkreditan Rakyat Syariah) sudah mencapai 86 unit dan masih akan bertambah. Di tahun-tahun mendatang, jumlah bank syariah ini akan terus meningkat seiring dengan masuknya pemain-pemain baru, bertambahnya jumlah kantor cabang bank syariah yang sudah ada, maupun dengan dibukanya Islamic Window di bank-bank konvensional.

Dari sebuah riset yang dilakukan oleh Karim Business Consulting, diproyeksikan bahwa total aset bank syariah di Indonesia akan tumbuh sebesar $2850 \%$ selama 8 tahun, atau rata-rata tumbuh $356.25 \%$ tiap tahunnya. Sebuah pertumbuhan aset yang sangat mengesankan. Tumbuh kembangnya aset bank syariah ini dikarenakan adanya kepastian disisi regulasi serta berkembangnya pemikiran masyarakat tentang keberadaan bank syariah.

Perkembangan perbankan syariah ini tentunya juga harus didukung oleh sumber daya insani yang memadai, baik dari segi kualitas maupun kuantitasnya. Namun realitas yang ada menunjukkan bahwa masih banyak sumber daya insani yang selama ini terlibat di institusi syariah tidak memiliki pengalaman akademis maupun praktis dalam Islamic Banking. Tentunya kondisi ini cukup signifikan mempengaruhi produktifitas dan profesionalisme perbankan syariah itu sendiri. Dan inilah memang yang harus mendapatkan perhatian dari kita semua, yakni mencetak sumber daya insani yang mampu mengamalkan ekonomi syariah di semua lini. Karena sistem yang baik tidak mungkin dapat berjalan bila tidak didukung oleh sumber daya insani yang baik pula. (Adiwarman Karim, 2003:29-30). 
Berdasarkan uraian latar belakang diatas maka permasalahan yang dapat diambil adalah: Bagaimana periodisasi perkembangan hukum perbankan syariah di indonesia.

\section{TINJAUAN PUSTAKA}

Di Indonesia pelopor perbankan syariah adalah Bank Muamalat Indonesia. Berdiri tahun 1991, bank ini diprakarsai oleh Majelis Ulama Indonesia (MUI) dan pemerintah serta dukungan dari Ikatan Cendekiawan Muslim Indonesia (ICMI) adalah beberapa pengusaha muslim. Bank ini sempat terimbas oleh krisis moneter pada akhir tahun 90-an sehingga ekuitasnya hanya tersisa sepertiga dari modal awal. IDB kemudian memberikan suntikan dana kepada bank ini dan pada periode 19992002 dapat bangkit dan menghasilkan laba. Saat ini keberadaan bank syariah di Indonesia telah diatur dalam Undang-undang Nomor 10 Tahun 1998 tentang Perubahan Undang-undang Nomor 7 Tahun 1992 tentang Perbankan.

Pada tahun 2007 terdapat 3 institusi bank syariah di Indonesia yaitu Bank Muamalat Indonesia, Bank Syariah Mandiri dan Bank Mega Syariah. Sementara di bank umum yang telah memiliki unit usaha syariah adalah 25 bank, diantaranya merupakan bank besar seperti Bank Negara Indonesia (Persero) dan Bank Rakyat Indonesia (Persero). Sistem syariah juga telah digunakan oleh Bank Perkreditan Rakyat, saat ini telah berkembang 104 BPR Syariah. Dan pada tahun 2012, ada 11 BUS, 24 UUS dan 155 BPRS Syariah. (Sri Indah Nikensari, 2012: 62-63)

Tonggak sejarah yang sangat penting untuk mencapai cita-cita umat muslim dalam perekonomian Islam adalah dengan dibentuknya Bank Pembangunan Islam/IDB (Islamic Development Bank), berdasarkan Deklarasi yang dikeluarkan oleh Konferensi Menteri Keuangan kalangan Negara Islam, yang tergabung dalam OKI, yang diselenggarakan di Jeddah, pada tahun 1973, dan resmi dibuka pada pada tanggal 20 Oktober 1975. (Nurul Hak,2011:15)

Setelah berdiri, Islamic Develepmen Bank (IDB) juga membantu berdirikan 
bank-bank Islam diberbagai negara. Untuk pengembangan sistem ekonomi syariah, institut ini membangun sebuah institut riset dan pelatihan untuk pengembangan penelitian dan pelatihan ekonomi Islam, baik dalam bidang perbankan maupun keuangan secara umum. Lembaga ini disingkat IRTI (Islamic Researc Training Institute). (M. Syafi'i Antonio,2002:21)

Berdirinya Islamic Develepmen Bank (IDB) telah memotivasi banyak negara Islam untuk mendirikan lembaga keuangan syariah. Untuk itu, komite ahli IDB pun bekerja keras menyiapkan panduan tentang pendirian, peraturan dan pengawasan bank syariah. Kerja keras mereka membuahkan hasil. Pada akhir periode 1970 dan awal 1980, bank syariah bermunculan di Mesir, Sudan, Negara-negara Telik, Pakistan Malaysia, Bangladesh dan Turki.

Di Indonesia, pendirian bank syariah, sudah lama dicita-citakan oleh Umat Islam, hal ini terungkap dalam keputusan Majlis Tarjih Muhammadiyah yang di adakan di Sidoarjo, Jawa Timur pada tahun 1968, dalam poin no 4 diputuskan, Majlis Tarjih menyarankan kepada Pimpinan Pusat Muhammadiyah untuk mengusahakan terwujudnya konsepsi sistem perekonomian, khususnya lembaga perbankan yang sesuai dengan kaidah Islam. (Suhrawardi K. Lubis, 2000:47)

Kata Bank berasal dari kata banque dalam bahasa Prancis, dan dari banco dari bahasa Itali, yang berarti peti/ lemari atau bangku. Kata peti atau lemari sebagai isyarat fungsi untuk tempat penyimpanan benda-benda berharga, seperti peti uang, peti emas atau yang lainya. Secara umum pengertian Bank Islam (Islamic Bank) adalah bank yang pengoperasiannya disesuaikan dengan prinsip syariat Islam. Saat ini banyak istilah yang diberikan untuk menyebut entitas Bank Islam selain istilah Bank Islam itu sendiri, yakni Bank Tanpa Bunga (Interest-Free Bank), Bank Tanpa Riba (Lariba Bank), dan Bank Syari'ah (Shari'a Bank). Di Indonesia secara teknis yuridis penyebutan Bank Islam mempergunakan istilah resmi "Bank Syari'ah", atau yang secara lengkap disebut "Bank Berdasarkan Prinsip Syari'ah”. 
Perkembangan bank syariah di dunia dan di Indonesia tetap mengalami kendala karena bank syariah hadir di tengah perkembangan dan praktik perbankan konvensional yang sudah mengakar dalam kehidupan masyarakat secara luas. Kendala ini tidak terlepas dari belum tersedianya sumber daya manusia secara memadai dan peraturan perundang- undangan, meskipun telah banyak kajian yang mencoba untuk mempermudah penjelasan tentang pelaksanaan operasional perbankan syariah.

Hal tersebut mengingat bahwa di tiap-tiap negara, terutama yang masyarakat mayoritas muslim, tidak mempunyai infrastruktur pendukung dalam operasional perbankan syariah secara merata. Konsekuensi perkembangan di tiap-tiap negara tentunya akan berdampak, baik langsung maupun tidak langsung terhadap perkembangan perbankan syariah di dunia. Apalagi saat ini ketika produk-produk keuangan semakin cepat perkembangannya. (Khaerul Umam, tt: 21-22)

Gagasan suatu sistem ekonomi Islam berangkat dari keprihatinan dunia Islam tentang penerapan sistem bunga pada bank konvensional yang oleh sebagian kalangan mus- lim dianggap termasuk dalam kategori riba. Oleh karena itu pada dasawarsa 70-an, ketika untuk pertama kali muncul pemikiran tentang sistem ekonomi Islam dalam Konferensi Internasional tentang Ekonomi Islam di Mekkah pada tahun 1976. (Marulak Pardede \& Ahyar, 2005,:13)

Sekalipun masyarakat indonesia merupakan masyarakat muslim terbesar di Dunia, kehadiran bank yang berdasarkan syariah masih relatif baru, yaitu baru pada awal tahun 1990-an. Namun diskusi tentang bank syariah sebagai basis ekonomi Islam sudah mulai dilakukan pada awal tahun 1980. Sedangkan prakarsa untuk mendirikan bank syariah di Indonesia dilakukan oleh Majelis Ulama Indonesia (MUI) pada tanggal 18-20 Agustus 1990.

Lahirnya bank syariah pertama di Indonesia yang merupakan hasil tim perbankan MUI adalah dengan dibentuknya PT. Bank Muamalat Indonesia (BMI) 
yang akte pendiriannya ditandatangani tanggal 1 November 1991. Saat ini BMI sudah memiliki puluhan cabang yang tersebar dibeberapa kota besar seperti Jakarta, Surabaya, Bandung, Makasar dan kota-kota lainnya.

Disamping BMI, saat ini juga telah lahir Bank Syari- ah milik pemerintah seperti Bank Syariah Mandiri (BSM). Kemudian berikutnya berdiri Bank Syariah sebagai cabang dari bank konvensional yang sudah ada, seperti Bank BNI, Bank IFI, Bank BPD Jabar, Bank-bank Syariah lain yang diren- canakan akan membuka cabang adalah BRI, Bank Niaga dan Bank Bukopin. (Kamsir, 2004. Hlm. 215-216)

Seperti sudah dijelaskan sebelumnya, bahwa jenis bank jika dilihat dari cara mentukan harga terbagi menjadi

2 macam, yaitu bank yang berdasarkan bank konvensional dan bank yang berdasarkan prinsip syariah. Hal pertama yang menjadi perbedaan antara kedua jenis bank ini adalah dalam hal penentuan harga, baik untuk harga jual maupun harga beli. Dalam bank konvensional penentuan harga selalu didasarkan kepada bunga, sedangkan dalam bank syariah didasarkan kepada konsep Islam yaitu kerjasama dalam skema bagi hasil, baik untung maupun rugi.

Sejarah, awal mula kegiatan bank syariah yang pertama sekali dilakukan adalah di Pakistan dan Malaysia pada sekitar tahun 1940an. Kemudian di Mesir pada tahun 1963 berdiri Islamic Rural Bank di desa It Ghamr Bank. Bank ini beroperasi di pedesaan mesir dan masih berskala kecil. (Kamsir, 2002:177)

Kehadiran bank syariah ternyata tidak hanya dilakukan oleh masyarakat muslim, akan tetapi juga bank milik non muslim. Saat ini bank Islam sudah tersebar diberbagai negara- negara muslim dan non muslim, baik di benua Amerika, Australia dan Eropa. Bahkan banyak perusahaan keuangan dunia seperti ANZ, Chase Chemical Bank dan Citibank telah membuka cabang yang berdasarkan syariah. (Kamsir, 2002:179) 


\section{HASIL PENELITIAN DAN PEMBAHASAN}

Perkembangan Hukum Perbankan Syariah di Indonesia

Kata Hukum (al-hukm) secara bahasa bermakna menetapkan atau memutuskan sesuatu, sedangkan pengertian hukum secara terminologi berarti menetapkan hukum terhadap segala sesuatu yang berkaitan dengan perbuatan manusia (Burhanuddin Susanto, 2008:7) dalam perihal ini berarti penetapan hukum yang berkaitan dengan Perbankan.

Undang-Undang No. 10 Tahun 1998 pengertian Bank adalah berupa badan usaha yang menghimpun dana dari masyarakat dalam bentuk simpanan dan menyalurkanya kepada masyarakat dalam bentuk kredit dan atau bentuk- bentuk lainya dalam rangka meningkatkan taraf hiduporang banyak (Pasal 1 Angka 2). Perbankan adalah segala sesuatu yang menyangkut tentang Bank, mencakup kelembagaan, kegiatan usaha, serta cara dan proses dalam melaksanakan kegiatan usahanya (Pasal 1 angka 1). (Burhanuddin Susanto,2008:17)

Berkaitan dengan perkembangan hukum ekonomi di Indonesia dari sistem hukum ekonomi konvensional ke arah hukum ekonomi syariah, maka terdapat dualisme hukum ekonomi dalam hukum positif Indonesia. Hal ini tentu saja mempengaruhi kurikulum dan materi muatan bahan ajar di lingkungan fakultas terkait, yaitu fakultas ekonomi dan fakultas hukum. Salah satu bidang kekhususan di lingkungan fakultas hukum Unpad adalah bidang hukum ekonomi. Bidang kekhususan hukum ekonomi ini selanjutnya didukung oleh beberapa matakuliah baik wajib program kekhususan maupun wajib fakultas dan mata kuliah pilihan. Beberapa mata kuliah baik yang wajib maupun pilihan bagi mahasiswa yang mengambil program kekhususan hukum ekonomi antara lain: hukum ekonomi, hukum perbankan, hukum Surat Berharga dan Pasar Modal, kapita Selekta hukum perjanjian, yang banyak membahas hukum pembiayaan, hukum penanaman modal, hukum asuransi. Di sisi lain, hukum Islam diberikan sebagai mata kuliah sendiri, dan lebih 
banyak menelaah hukum Islam secara umum, termasuk aktivitas ekonomi Islam.

Ekonomi syari'ah adalah, “perbuatan atau kegiatan usaha yang dilaksanakan menurut prinsip syari'ah" (lihat Penjelasan Pasal 49 huruf i Undang-Undang No. 3 Tahun 2006). Prinsip dasar syari'ah yang membedakan ekonomi syari'ah dengan ekonomi konvensional adalah ridha,(kebebasan berkontrak), ta'awun, bebas riba, bebas gharar, bebas tadlis, bebas maisir, objek yang halal dan amanah.

Bank syariah terdiri dari dua kata, yaitu (a) bank, dan (b) syariah. Kata bank bermakna suatu lembaga keuangan yang berfungsi suatu perantara keuangan dari dua pihak, yaitu pihak yang berkelebihan dana dan pihak yang kekurangan dana. Kata syariah dalam versi bank syariah di Indonesia adalah aturan perjanjian berdasarkan yang dilakukan oleh pihak bank dan pihak lain untuk penyimpangan dana dan/ atau pembiayaan kegiatan usaha dan kegiatan lainnya sesuai dengan hukum islam.

Penggabungan kedua kata dimaksud, menjadi “bank syariah”. Bank syariah adalah suatu lembaga keuangan yang berfungsi sebagai perantara bagi pihak yang berkelebihan dana dengan pihak yang kekurangan dana untuk kegiatan usaha dan kegiatan lainnya sesuai dengan hukum islam. Selain itu, bank syariah biasa disebut Islamic banking atau interest fee banking, yaitu suatu system perbankan dalam pelaksanaan operasional tidak menggunakan sistem bunga (riba), spekulasi (maisir), dan ketidak pastian atau ketidak jelasan (gharar). (Zainuddin Ali, 2010:1)

Sama seperti halnya dengan bank konvensional, bank syariah juga menawarkan nasabah dengan beragam produk perbankan. Sanya saja bedanya dengan bank konvensional adalah dalam hal penentuan harga, baik terhadap harga jual maupun harga belinya. Produk-produk yang ditawarkan sudah tentu sangat islami, termasuk dalam memberikan pelayanan terhadap nasabahnya. Berikut ini jenis-jenis produk bank syariah yang ditawarkan adalah sebagai berikut: Al-wadi'ah (Simpanan), Pembiayaan dengan bagi hasil, Bai'al-Murabahah, Bai'as-salam, Bai' Al-istihna', Al- Ijarah (Leasing), Al-Wakalah (Amanat), Al-Kafalah(Garansi), Al- 
Hawalah, Ar-Rahn. (Kamsir, 2002:179-180)

Bank Syariah secara yuridis formal di Indonesia

memiliki dasar diantaranya:

a) Undang-Undang Nomor 7 tahun 1992 tentang Perbankan

b) Undang-Undang Nomor 10 tahun 1998 tentang Perubahan atas UndangUndang Nomor 7 tahun 1992 tentang Perbankan

c) Undang-Undang Nomor 23 tahun 1999 tentang Bank Indonesia

d) Undang-Undang Nomor 3 tahun 2004 tentang Perubahan atas UndangUndang Nomor 23 tahun 1999 tentang Bank Indonesia

e) Undang-Undang Nomor 7 tahun 1989 tentang Peradilan Agama Undang-Undang Nomor 3 tahun 2006 tentang Perubahan atas

f) Undang-Undang Nomor 7 tahun 1989 tentangPeradilan Agama

g) Undang-Undang Nomor 21 tahun 2008 tentang Perbankan Syariah Urgensi Undang-Undang Perbankan Syariah

Bank syariah merupakan salah satu intrumen yang digunakan untuk menegakkan aturan-aturan ekonomi Islam. Sebagai bagian dari sistem ekonomi, lembaga tersebut merupakan bagian dari keseluruhan sistem sosial. Oleh karenanya, keberadaannya harus dipandang dalam konteks keseluruhan keberadaan masyarakat (manusia), serta nilai- nilai yang berlaku dalam masyarakat yang bersangkutan. (Dwi Suwiknyo, 2010:1-2)

Namun disisi lain tujuan ekonomi syariah ternyata mempunyai kesamaan dengan tujuan hukum. Menurut Gustav Radbruch, hukum mempunyai tujuan untuk mewujudkan keadilan, kemanfaatan, dan kepastian Hukum. Sedangkan menurut Prof. Subekti, Hukum mempunyai tujuan untuk untuk mengabdi pada tujuan negara yaitu mendatangkan kemakmuran dan kebahagiaan melalui penyelenggaraan keadilan dan ketertiban. Sehingga adanya hukum dalam perbankan syariah merupakan perwujudan dari tujuan negara Indonesia. Berdasarkan hal tersebut, maka diketahui bahwa tujuan Jurnal Al-Dustur; VOLUME 2 NO 1, JUNI 2019 
ekonomi syariah dan tujuan hukum mempunyai satu persamaan yaitu hendak mewujudkan suatu keadilan dan kesejahteraan didalam masyarakat.

Bisnis berdasarkan syariah di negeri ini tampak mulai tumbuh. Pertumbuhan itu tampak jelas pada sektor keuangan. Dimana kit telah mencatat tiga bank umum syariah, 78 BPR Syariah dan lebih dari 2000 unit Baitul Mal wa Tamwil. Lembaga ini telah mengelola berjuta bahkan bermiliard rupiah dana masyarakat sesuai dengan prinsip syariah. Lembaga keuangan tersebut harus beroperasi secara ketat berdasarakn prinsip-prinsip syariah. Prinsip ini sangat berbeda dengan prinsip yang dianut oleh lembaga keuangan non syariah. Adapun prinsip-prinsip yang dirujuk adalah:

a) Larangan menerapkan bunga pada semua bentuk dan jenis transaksi;

b) Menjalankan aktivitas bisnis dan perdagangan berdasarkan pada kewajaran dan keuntungan yang halal;

c) Mengeluarkan zakat dari hasil kegiatannya;

d) Larangan menjalankan monopoli; dan

e) Bekerjasama dalam membangun masyarakat, melalui aktifitas bisnis dan perdagangan yang tidak dilarang oleh Islam. (Dwi Suwiknyo, 2010:3)

Ketika hati dan pikiran telah sedemikian lama terkungkung oleh sistem ribawi, ide bank Islam yang dimunculkan oleh Majelis Ulama Indonesia seakan- akan membuat umat Islam kesulitan mencari rujukan. Alhamdulillah, UU Perbankan No. 7 tahun 1992 memberikan peluang berdirinya bank syariah. Sekarang, setelah bank syariah beroperasi tujuh tahun dan UU perbankan No. 10 Tahun 1998 diterbitkan, beberapa bank akan mengubah sistem operasinya menjadi bank syariah, baik secara keseluruhan maupun hanya mendirikan cabang-cabang syariah. Sekali lagi umat Islam gamang mencari rujukan bagaimana mengkonversi bank-bank umum menjadi bank syariah.

Sebenarnya, ada beberapa pengalaman yang dapat dirujuk. Sudan dan Iran 
dapat dijadikan rujukan bagaimana mereka mengkonversi sistem perbankan konvensional menjadi perbankan syariah. merujuk pada pengalaman Iran, konversi ini dapat dilakukan beberapa tahapan. Pertama, konversi sisi liabilitas (tabungan, deposito). Pada 1983, pemerintah Iran melakukan konversi ini “dalam satu hari”, yaitu dengan mengumumkan bahwa bank tidak lagi membayar bunga, tapi bagi hasil. Namun, sisi aset baru benar-benar dapat di konversi seluruhnya pada 1986, artinya makan waktu tiga tahun, tahap demi tahap.

Ke dua, mengkonversi kredit-kredit yang berbasiskan kepemilikan antiva tetap menjadi skim murabahah (jual beli). Ini pun harus dinegosiasikan akad barunya dengan debitor. Ke tiga, mengkonversi L/C, Bank Garansi dan produk yang berbasiskan fee menjadi skim joala dan ijarah. Ke empat, mengkonversi kredit kepemilikan rumah menjadi skim musyarakah mutanakisah. Ke lima, mengkonversi kredit modal kerja menjadi Mudharabah dan musyarakah. Ke enam, mengkonversi pinjaman murni menjadi qard. Ke tujuh, mengkonversi skim pasar uang antar bank menjadi sesuai syariah. (Adiwarman A. Karim, 2001:76)

Lahirnya UU No. 10 tahun 1998 tentang perubahan atas UU No 7 tahun 1992 tentang perbankan, telah memungkinkan bank syariah beroperasi sepenuhnya sebagai Bank Umum Syariah (BUS) atau dengan membuka Unit Usaha Syariah (UUS). Lahirlah Bank Syariah Mandiri (konversi dari Bank Susila Bakti) serta UUS Bank IFI. Pada akhir tahun 1999, total aset bank syariah di Indonesia baru mencapai Rp 1,12 triliun atau sekitar $0,11 \%$ dibandingkan dengan dengan aset bank konvensional.

Kemudian, lahirlah beberapa bank syariah yang lain, sehingga pada desember 2002 terdapat 2 BUS dan 6 UUS, dengan total aset mencapai Rp 4,05 triliun. Pada 16 Desember 2003, Majelis Ulama Indonesia (MUI) mengeluarkan fatwa tentang haramnya bunga bank yang menyebabkan terjadinya unorganic grawth. Hingga Desember 2004, total bank syariah mencapai 3 BUS dan 15 UUS dengan total aset Rp 15,33 triliun. (Khaerul Umam, tt:22-23). 
Perbankan Syariah dalam Peraturan Pemerintah

Sekurang-kurangnya terdapat tiga Peraturan Pemerintah sebagai turunan dari UU No.7/1992 antara lain: PP No.70/1992 tentang Bank Umum, PP No.71/1992 tentang Bank Perkreditan Rakyat dan PP No.71/1992 tentang Bank Berdasarkan Prinsip Bagi Hasil. Disebutkan pula dalam pasal 5 ayat (3) PP No.70/1992 bahwa: "Bank Umum yang beroperasi berdasarkan prinsip bagi hasil, dalam rancangan anggaran dasar dan rencana kerja harus secara tegas mencantumkan kegiatan usaha Bank yang semata-mata berdasarkan prinsip bagi hasil”.

Kemudian dalam pasal 6 ayat (2) PP No.71/1992 ten- tang Bank Perkreditan Rakyat dibutuhkan bahwa: "Bank Per- kreditan Rakyat yang akan melakukan kegiatan usaha ber- dasarkan prinsip bagi hasil harus secara tegas mencantumkan kegiatan usaha bank yang semata-mata berdasarkan prinsip bagi hasil dalam rancangan anggaran dasar dan rencana ker- janya." Ketentuan ini memberi kesempatan kepada lembaga keuangan syariah untuk menjalankan fungsinya berdasar- kan prinsip bagi hasil. Adapun PP No.72/1992 lebih banyak mengatur ketentuan-ketentuan yang lebih bersifat teknis bagi penyelenggaraan operasional bank syariah, yang mencakup atas pelayanan dan jasa perbankan syariah dalam kegiatan usaha bank syariah diarahkan untuk memenuhi kebutuhan masyarakat. (Ahmad Hasan Ridwan, 2013:19)

Perbankan Syariah dalam Peraturan Bank Indonesia

PBI yang lahir setelah 1 november 2004 harus menyesuaikan dengan ketentuan dalam UU No. 10 tahun 2004. Karena PBI tidak termasuk dalam hierarki hukum nasional. Oleh karena itu, proses kelahirannya, PBI harus ada perintah dari peraturan perundang-undangan yang disebutkan dalam pasal 7, yaitu UUD, Perpu, UU, PP, dan Perpres 4 UU No. 10 Tahun 2004).

Dalam UU Perbankan Syariah banyak pasal-pasal yang memerintahkan 
"ketentuan lebih lanjut mengenai hal tertentu diatur dalam PBI." Terdapat 21 ketentuan dalam UU Perbankan Syariah yang memerintahkan pengaturan lebih lanjut hal tertentu dalam PBI.

Beberapa peraturan Bank Indonesia dalam perbankan syariah:

- PBI No.6/24/PBI/2004 tentang bank umum yang melaksnakan kegiatan usaha berdasarkan prinsip syariah

- PBI No.7/35/PBI/2005 tentang perubahan atas peraturan bank Indonesia No. 6/24/PBI/2004 tentang bank umum yang melaksanakan kegiatan usaha berdasarkan prinsip syariah

- PBI No.9/19/PBI/2007 tentang pelaksanaan prinsip syariah dalam kegiatan penghimpunan dana dan penyaluran dana serta pelayanan jasa bank syariah. Dewan Syariah Nasional (DSN)

Dewan Syariah Nasional (DSN) adalah dewan yang dibentuk oleh MUI untuk menangani maslah-masalah yang berhubungan dengan aktifitas lembaga keuangan syariah. DSN merupakan bagian dari Majelis Ulama Indonesia (MUI) yang bertugas menumbuh kembangkan penerapan nilai-nilai syariah dalam kegiatan perekonomian pada umumnya dan sektor keuangan pada khususnya, termasuk usaha bank, asuransi dan reksadana, pegadaian syariah dan pasar modal syariah. Badan ini mempunyai pelaksana harian yang disebut badan pelaksana harian Dewan Syariah Nasional (DSN) ada- lah badan yang sehari-hari melaksanakan tugas DSN. Kemu- dian DSN ini membentuk dewan syariah yang melaksanakan keputusan DSN yaitu Dewan Pengawas Syariah (DPS). (Ah- mad Supriyadi, 2011:33)

Anggota DSN terdiri dari para ulama, praktisi dan pakar dalam bidangbidang yang terkait dengan perekonomian dan syariah muamalah. Anggota DSN ditunjuk dan diangkat oleh MUI untuk masa bakti 4 tahun.

DSN merupakan satu-satunya badan yang mempunyai kewenangan mengeluarkan fatwa atas jenis-jenis kegiatan, produk dan jasa keuangan syariah serta Jurnal Al-Dustur; VOLUME 2 NO 1, JUNI 2019 
mengawasi penerapan fatwa dimaksud oleh lembaga-lembaga keuangan syariah di Indonesia. (Ahmad Supriyadi, 2011:33-34)

Salah satu tujuan fatwa DSN adalah melindungi operasional institusi keuangan syariah agar berjalan sesuai dengan kaidah-kaidah syariah. Fatwa-fatwa yang dikeluarkan DSN terfokus pada bidang ekonomi syariah. Keberadaan fatwa DSN menjadi signifikan dalam pembangunan hukum ekonomi syariah di Indonesia maka fatwa-fatwa ekonomi syariah dikeluarkan oleh DSN sebenarnya mempunyai keterkaitan dengan materi yang dibahas dalam KHES. Kemudian, fatwa-fatwa DSN juga menggambarkan hajat masyarakat akan landasan hukum dan tindakan dalam melakukan syariah. Oleh karena itu, dalam beberapa bidang dan pasal-pasal tertentu, fatwa DSN "dikopi" begitu saja dengan beebrapa perubahan yang sifatnya redaksional.

(Juhaya S. Pradja, 2012:207-208)

Banyaknya DSN di masing-masing lembaga keuangan syariah menimbulkan keragaman dalam memberikan fatwa syariah hal itu adalah suatu hal yang harus disyukuri, tetapi juga diwaspadai. Kewaspadaan itu berkaitan dengan adanya kemungkinan timbulnya fatwa yang berbeda-beda dari masingmasing oleh DSN. Akibatnya akan membingungkan umat dan nasabah dilembaga keuangan syariah. Oleh karena itu, MUI sebagai payung dari lembaga dan organisasi ke- Islaman di tanah air, menganggap perlu di bentuknya satu dewan syariah yang bersifat nasional dan membawahi seluruh lembaga keuangan, termasuk di dalamnya bank- bank syariah. Lembaga ini kemudian dikenal dengan Dewan Syariah Nasional (DSN). (Ahmad Supriyadi, 2011:35).

\section{PENUTUP}

Berdasarkan pembahasan di atas dapat disimpulkan bahwa: Perbankan syariah atau perbankan Islam adalah suatu sistem perbankan yang pelaksanaannya berdasarkan hukum Islam (Syariah). Periodisasi perkembangan hukum dalam 
perbankan syariah juga menjadi salah satu faktor menonjolnya aset perbankan syariah dalam ekonomi syariah dibandingkan dengan produk ekonomi syariah lain. Untuk mencapai akselerasi perekonomian syariah Indonesia, seharusnya keberhasilan hukum dalam mengembangkan perbankan syariah dapat menjadi contoh produk ekonomi syariah lain untuk berkembang. Hal ini dikarenakan hukum dapat memberikan keuntungan yang besar secara langsung maupun tidak langsung bagi seluruh pihak dalam ekonomi syariah. Hukum dalam ekonomi syariah juga dapat berperan sebagai alat untuk memenuhi, melindungi dan memajukan hak setiap rakyat Indonesia atas kesejahteraan dan keadilan melalui perekonomian syariah. Hal ini merupakan tantangan bagi pemerintah/policy maker untuk dapat membuat peraturan. 
16 | Juhasdi Susono

\section{REFERENSI}

Abdul Ghofur Anshori, Kapita Selekta Perbankan Syariah di Indone- sia, UII Press, Yogyakarta, 2008.

Adiwarman Karim, Bank Islam (Analisis Fiqih dan Keuangan), IIIT (The International Institute of Islamic Thought) Indonesia, Jakarta, 2003.

Adiwarman A. Karim, Ekonomi Islam Suatu Kajian Kontemporer, Gema Insani Press, Jakarta, 2001.

Ahmad Supriyadi, Bank Syariah (Studi Perbankan Syariah dengan Pendekatan Hukum), Idea Press Yogyakarta, 2011.

Ahmad Hasan Ridwan, Manajemen Baitul Mal wa Tamwil, CV.

Pustaka Setia, Bandung, 2013.

Burhanuddin Susanto, Hukum Perbankan Syariah di Indonesia, UII Pres, Yogyakarta, 2008.

Dwi Suwiknyo, Jasa-jasa Perbankan Syariah, Pustaka Pelajar, Yo- gyakarta, 2010.

Fathurrahman Djamil, Hukum Ekonomi Islam (Sejarah, Teori dan Konsep), Sinar Grafika, Jakarta, 2013.

Heri Sudarsono, Konsep Ekonomi Islam (Suatu Pengantar), Ekoni- sia, Yogyakarta, 2002.

Juhaya S. Pradja, Ekonomi Syariah, CV. Pustaka Setia, Bandung, 2012.

Kamsir, Dasar-dasar Perbankan, PT. Raja Grafindo Persada, Jakar- ta, 2004.

, Bank \& Lembaga Keuangan Lainnya, Edisi keenam, PT. Raja Grafindo Persada, Jakarta, 2002. 
Khaerul Umam, Manajemen Perbankan Syariah, CV Pustaka Setia, Bandung.

Marulak Pardede \& Ahyar, Problem Dual Banking System, dalam Buletin Hukum Perbankan \& Kebanksetralan Vol. 3 - 1 April 2005.

Mervyn K. Lewis\&Latifa M. Algaoud, Perbankan Syariah (Prinsip, Praktik, dan Prospek), PT. Serambi Ilmu Semesta, Jakarta, 2005.

Muhammad Djumhana, Hukum Perbankan di Indonesia, PT Citra Aditya Bhakti,Bandung: 2003.

M. Nur Yasin, Hukum Ekonomi Islam (Geliat Perbankan Syariah di Indonesia), UIN-Malang Press. 2009.

M. Syafi'i Antonio, Bank Syariah Dari Teori ke Praktek, Gema In- sani, Jakarta, 2002.

Nurul Hak, Ekonomi Islam Hukum Bisnis Syariah (Mengupas Ekonomi Islam, Bank Islam, Bunga Uang dan Bagi Hasil, Wakaf Uang dan Sengketa Ekonomi Syariah), Teras, Yog- yakarta, 2011.

Said Sa'ad Marthon, Ekonomi Islam di Tengah Krisis Ekonomi Glob-al, Zikrul Hakim, Jakarta. 2007.

Sri Indah Nikensari, Perbankan Syariah (prinsip, sejarah \& aplikasin- ya), PT. Pustaka Rizki Putra, Semarang. 2012.

Zainul Arifin, Memahami Bank Syariah: Lingkup, Peluang, Tantan- gan dan Prospek, Alfabet, Jakarta, 1999.

Zainuddin Ali. Hukum Perbankan Syariah, Sinar Grafika, Jakarta, 2010. 